IRSTI 14.25 .09

\author{
Arinova B. \\ candidate of pedagogical sciences, \\ Al-Farabi Kazakh national university, Kazakhstan, Almaty, e-mail: baxit-a@mail.ru
}

\title{
TECHNOLOGIES OF WORK OF THE SOCIAL TEACHER WITH GIFTED CHILDREN
}

The technology and work of the social teacher with gifted children is considered in the article The giftedness is a special quality of the person transferred from the birth and abilities of the person with versatility of giftedness. In pedagogics «giftedness» is understood as extensiveness of human opportunities, as the general abilities defining efficiency of activity, intellectual potentials, informative opportunities of training and integrity of abilities and also talent of the person from the birth. In this regard the author analyzing definitions «giftedness» gives an explanation to such types of giftedness as intellectual, academic, art, creative, sports, leader and social. In this article the giftedness is considered as one of types of deviations therefore it is characterized features of work of the social teacher. The determination ways of children giftedness, types of works with parents of gifted children, consultation ethics, special questionnaires and psychodiagnostic trainings reveal. The author offers examples of exercises and tasks which he is used for development of memory of giftedness children, makes recommendations about their performance.

Key words: giftedness, opportunity, ability, social teacher, deviation, intelligence of mind, feature of children.

\author{
Әрінова Б.А. \\ педагогика ғылымдарының кандидаты, \\ әл-Фараби атындағы Қазақ, ұлттық университеті, Қазақстан Республикасы, Алматы қ., \\ e-mail: baxit-a@mail.ru
}

Әмеуметтік педагогтің дарынды балалармен жұмыс жасау технологиямары

Мақалада әлеуметтік педагогтің дарынды балалармен жұмыс жасау технологиялары, олармен жүргізілетін жұмыс түрлері қарастырылады. Аарындылық - аламның туа біткен ерекше қасиеті болып саналады. ААам бойындағы әртүрлі қабілеттіліктерге орай дарындылықтың көп қырлылығын көруге болады. Педагогика ғылымында "дарындылық" деп адам мүмкіндіктерінің кеңдігі мен қызмет өнімдігін айқындайтын жалпы қабілеттер, ақыл әлеуеті, оқуға деген танымдық мүмкіндіктер мен қабілеттердің біртұтас сипаттамасын және туа біткен табиғи талантты айтады. Осыған орай автор “дарындылық" ұғымына берілген анықтамаларға та^дау жасай отырып, оның интемлектуалды, академиялық, көркемдік, шығармашылық, спорттық, мидерлік және әлеуметтік деген түрлеріне түсінік береді. Аталған мақалада дарындылық ауытқушылықтың бір түрі ретінде қарастырылып, әлеуметтік педагогтің дарынды баламен жұмыс жасаудағы өзіндік ерекшеліктері сипатталады. Баланың дарындылығын анықтау жолдары, әлеуметтік педагогтің дарынды баланың ата-анасымен жүргізетін жұмыстарының түрлері, кеңес беру этикасы, арнайы сауа^нама^ар және психодиагностикалық тренингтер жөнінде айтылады. Автор дарынды баланың есте сақтау қабілетін дамытуға байланысты орындалатын тапсырмалардың үлгісін ұсынады және берілген тапсырмаларды орындаудың нұсқаулығын көрсетеді.

Түйін сөздер: дарындылық, мүмкіндік, қабілет, әлеуметтік педагог, ауытқушылық, ақыл әлеуеті, баланың ерекшеліктері. 
Аринова Б.А.

кандидат педагогических наук, доцент кафедры педагогики и образовательного менеджмента, Казахский национальный университет имени аль-Фараби, Республика Казахстан, г. А^маты, e-mail: baxit-a@mail.ru

\title{
Технологии работы социального педагога с одаренными детьми
}

\begin{abstract}
В статье рассматривается технология и работа социального педагога с одаренными детьми. ОАаренность - это особое качество человека, переданное от рождения. Способности человека указывают на многогранность одаренности. В педагогике «одаренность» понимается как обширность человеческих возможностей, как общие способности, определяющие продуктивность деятельности, интемлектуальный потенциал, познавательные возможности обучения и целостность способностей, а также талантливость человека от рождения. В связи с этим автор, анализируя определения термина "одаренность», дает пояснение таким видам одаренности, как интемлектуальная, академическая, художественная, творческая, спортивная, мидерская и социалная. В Аанной статье одаренность рассматривается как один из видов девиаций, поэтому характеризуются особенности работы социального педагога, раскрываются пути определения одаренности детей, виды работ с родителями одаренных детей, этика консультирования, специальные опросники и психодиагностические тренинги. Автор предлагает примеры упражнений и задач, которые используются Аля развития памяти одаренных детей, Аает рекомендации по их выполнению.

КАючевые слова: одаренность, возможность, способность, социальный педагог, Аевиация, интемлект ума, особенности детей.
\end{abstract}

\section{Introduction}

According to social and economic changes of modern society, the great demand for gifted creative people with a high natural potential who differ from others in vigorous cogitative activity, ability to critically analyze problems, to make constructive decisions in various situations is observed. The purpose of formation of our country is search of talented young people and rendering pedagogical support and psychological assistance to them. These tasks are characterized by a combination of mental abilities of a human civilization as to one of the most important conditions of transition from the developed gifted person to gifted society.

The aim of the study is to generalize the technologies of the work of a social pedagogue with gifted children.

Materials and methods of research - a systematic and technological approach, a generalization of the technologies used in practice to work with gifted children.

\section{Literature review}

At any time people with the advanced knowledge were recognized in the history thanks to their contribution to development of the state and society. Thus, the gifted and talented youth is a bright future of our sovereign country that was confirmed by N.A. Nazarbayev having told: «We really need talents. Eventually, the state has to support and protect the talented sons and daughters». [1] According to the Law on formation of the Republic of Kazakhstan current problems of modern education and education «accounting of specific features at intellectual development of endowments, talent in each child» is considered. [2]

The giftednessis a natural feature of the person. From the point of view of various abilities inherent in the person, you can see many-sided value of the concept «giftedness». The problem of giftedness was considered in works of Ancient Greek philosophers where the opinion on "divine abilities» was created. Studying of human mentality during this era was one of the most complex problems as the philosophical ideas weren't uniform.Considering that every era has own reality, we can perceive differently arguments and essence of scientific results. From the point of view of self-updating of personal development we observe that this question speaks in many aspects. [3].For example, the European scientists who studied the giftedness nature in Renaissance, assumed that gifted people have to participate in government, and in the Middle Ages the level of mental capacities of people corresponded to their living conditions. Philosophical work of John Locke «About human understanding» says: «In people there are no congenital thoughts, they are based on experience; The Mind of the person when he is a child, is similar to a clean dish; there can't be in mind what isn't present in feelings» [4].

Representatives of the German classical philosophy said that studying of specifics of giftedness value of Kant and Hegel allowed to extend more widely philosophical concepts that it is possible to develop human giftedness and feeling of action. [5]. For the first time the giftedness was studied by the English anthropologist Francis Galton. For the first time he tried to prove that a gift - result of heredi- 
tary factors. His book «Heredity of Talent, Its Laws and Consequences» was one of the most widespread psychological works in the second half of the twentieth century. Speaking about giftedness, we rely on researches of the American scientist Joseph Renzulli about human intelligence and creativity. Studying experience of giftedness problem of ancient scientists time is used to this day.

Giftedness research problems from the pedagogical party began with Y.A. Komensky, I.G. Pestalozzi, A. Disterveg, J. Dewey, K.D. Ushinsky's works. These scientists attached great value to need to develop mental capacities at children.As the Kazakh educators recognized that the giftedness is inherent in natural quality, but also was noticed by them that education, work and the environment exerts huge impact on development of human abilities. Abay notes in the catchwords that the aspiration to learn and understand - a fine gift of the nature for people. He claims that thoughts and consciousness of the person are result of the work «some inherited qualities, and some are formed by work» [5].

The scientific basis of value of the term «giftedness» is reflected in works of the Russian teachers and psychologists. Scientific results of L. Vygotsky, B.G. Ananyev, V. A.Krutetskiy, N. Leytes, V. Teplov allowed to define structural components of giftedness and human abilities.Scientific-theoretical researches of giftedness is characterized by the following concepts: compliance of a phenomenon of intualny giftedness with age features (N. Leytes); creative ability of the person as manifestation of tendency to giftedness (A.A. Matyushkin, V.S. Yurkevich); dynamic theory of giftedness (Yu.D. Babayeva, N.A. Darkhanov, M.A. Holodnaya); transition within ecopsychological development of the person to development of giftedness (V.V. Panov). Thus, the theoretical analysis of psychology and pedagogical literature revealed the main directions of studying of children's giftedness. However development of children's talents was considered only in principle individual approach to development of mental and creative abilities of students. Therefore determination of giftedness is various. For example, S. V. Kuznetsova notes, «the talent of the children is a combination of mental capacities which can apply this knowledge in any situation, high activity, age, the high level of development of mental processes and a combination of intellectual qualities which provide good productivity». [7].

In the educational encyclopedia «Giftedness» it is the high level of abilities, which can help the person to achieve exclusive success in the field of actions. Ability to provide qualitative self-sufficien- cy of opportunities which succeed in service, common features or opportunities which define ability of the person to function and serve; intellectual potential or intelligence, informative ability to study and the individual characteristics of abilities, aggregation of abilities, natural indicators characteristic of the natural reasons of abilities and characteristics of their own level, talent; one of necessary conditions for big achievements in its work». [8].

To systematize these definitions, we can give definition that the talent is a question of parental dismissal. Features of the exceptional child are characterized its informative, memory and axiomatic qualities. In scientific theories, the following types of endowments are considered:

Intellectual talent;

Academic talent;

Art talent;

Creative talent;

Leadership and social talent;

Sports talent.

For definition of types of giftedness and the fields of psychiatry which provide it; extent of formation of gift, an observation form, observation width in a variety of kinds of activity; features of development, specific to concrete age. Classification of types of giftedness according to «Type of activity and psychiatric spheres provided to them» is more important for understanding of qualitative nature of giftedness.On criteria of extent of formation of gift, there are two types of giftedness the actual giftedness and potential giftedness. The actual giftedness is a psychological characteristic of the child who reaches a certain level of mental development, which is observed on high performance level in concrete subject domain in comparison with age and social norms. Talented children make special category of gifted children. The talented boy - the child who reaches objective innovations and socially important requirements.

The social giftedness is mental characteristic of the child having intellectual ability to achieve good results in a certain form of activity, but at the same time have no ability to carry out the functional shortcoming. This potential is at a loss a number of negative factors (a difficult family situation, lack of incentives, impossibility to control behavior, lack of the necessary educational environment, etc.). It is revealed that the potential giftedness is a pleasant situation, which provides concrete impact on development of initial psychological ability of the child.

It is possible to tell about obvious and hidden endowments by criteria of «an observation form». 
Obvious endowments it is clear from actions of the child. The talent of the child does not raise doubts, and his achievement is amazing. The hidden endowments are observed in the atypical, latent form, and others do not know about it. As a result, the wrong conclusion can be that the child is not gifted. It can be carried to «the uncertain future» and to be deprived of necessary support.

The reasons of the phenomenon of the hidden gift should be looked for in the cultural environment in which the child, in particular communication with surrounding people and in mistakes of adults in its education and development is formed. The hidden gift is a natural phenomenon. Detection of the hidden exceptional children is not limited to one-time psych diagnostic check. Identification of talented children of this kind - the long process based on multidisciplinary approach to the analysis of behavior of the child. In this measurement, work of the social teacher with exceptional children is carried out.

Width of the spectrum of action it is possible to summarize from the point of view of the general and concrete talent. The gross talent is observed in a number of kinds of activity and is a basis of their work. The most important aspect of endowments is cerebration and its sequence. As a rule, the talent is defined according to the level of suitability of the child, commitment degree.

The special endowments concern a certain kind of activity (poetry, mathematics, sport, communication, etc.).

The early and late talent can be referred to category «Features of Development of Age». It is possible to call an example of early talent «wounded». The word «whizz kid» is «the surprising boy». They are not worthy age, with improbable opportunities of mental development.

Now there is a high potential for identification and development of giftedness as a result of society, the social environment, school education. Work with modern technologies exerts considerable impact on identification and identification of exceptional children. How to define exceptional children? N.Leates is capable to divide children into three categories:

- The pupils having early age;

- Pupils who have a certain kind of activity and special type of school experience.

- The students gifted with talent.

Children of the first category are characterized by intensity of their study; their mentality becomes stronger, than their peers do. Children of the second category obviously show ability to adapt to concrete area. Children of the third category don't notice distinction, and these children don't go to the parents from the point of view of their general development, but they are, it seems, stunned with feature of mind. [9].

Most of teachers consider the best pupils talented. However, it can be wrong, apparently from the English psychologist P. Torrent. It was more attractive to pupils, than pupils who cannot read, discipline, politely, solid are well informed, stable, clever, clever, and capable to give the exact and clear ideas.It also means that each student who constantly asks questions, being engaged in the work, creatively, is not separated from the point of view of each certain pupil. Thus, by the words P. A torrent, it is possible to see that among needy pupils there are talented children.Here two ways of recognition of giftedness: 1) all children are talented; 2) talented children are very rare. Irrespective of features of such comments on endowments, we can tell that based on this phenomenon there are abilities which allow the person to achieve good results in one or several kinds of activity.

The character of the identity of the gifted child is characterized by the different level of quality. High level of cognitive requirements, aspiration to creative activity, aspiration to bigger knowledge, enthusiasm is a stimulating aspect of actions of talented children. Exceptional children can prove at early age.Perfectionism at most of exceptional children is characterized by perfection to perfection. Such children can repeat in certain cases work within several hours to finish complete work (composition, the drawing, model). This persistence can seem a step forward for future professional success, but it is no wonder that sometimes it will be more powerful. Therefore, the psychologist and the social teacher have to limit such claims.

Gifted children often prefer to be selfish in the actions, do not want to resort to anybody the help, nor to councils. It also shows that it does not distinguish it from others and that there are signs of a deviation. Therefore, the social teacher has to remember psychological features of work with the exceptional child.

Among gifted children with special abilities in a certain area, there is no intellectual development (synchronization). It directly influences her personality and is the beginning of many problems. Such children are much more advanced in intellectual or art and esthetic development.In most cases, there are problems with emotional development of these children. Many of them are very sensitive. Events, which are unattractive for other children, 
can cause concern. The criticism will probably worsen and worry. It can sometimes be exposed to psychosomatic pain. In this case, they do not want to participate in exercises, to play sports. The social teacher has to help to solve this problem and if it is made together with the school psychologist, the result will be positive.

Other part of gifted children - all enthusiasm of some intellectual children is aimed only at the development of scientific knowledge, which becomes the stimulating force of their cognitive activity. The fact that the exceptional child cannot achieve results is sometimes connected with family. If the parent does not pay attention to a separate symbol of the child, the child cannot be open. The dressed child needs deviant behavior in the childhood, needs support. Sometimes work of parents or other circumstances can result in unique abilities of the child.However bad social conditions of family, the low standard of living, the shortage of material, incomplete family, etc. doesn't exert direct impact on development of children's abilities because the most important in formation of the talented child is an attention of parents. Despite the lack of a situation, they pay special attention to training of the child, buy additional books and consult with the teacher how to train them. It is a positive factor in ability of the child to develop. In both cases, such divergences are of great importance for work of social teachers with their family and parents.

\section{Results and discussion}

In personal development of the gifted child, it is very effective to have the pedagogicpsychological analysis of its relations with adults and friends. In most cases, the behavior of especially exceptional children is characteristic of behavior, which leads to rejection and humiliation. For this reason, the social teacher together with the leader of a class has to organize exercises, trainings and games, which govern the relations between children. Social teachers with their family and parents.Such intervention will exert positive impact on such intervention will exert positive impact on their understanding and perception of each other. In addition, at special school for exceptional children, the mental ability of the talented boy will be estimated, and his relations with peers will be better. The attitude of teachers towards the talented child is also directly connected with their personal qualities. However, in certain cases there are also some shortcomings of children, which finally can be classified as difficult children. In this case, it should be noted that in work of the social worker his professional competence has to be observed.

The basis for identification of the exceptional child is based on teachers, but it is directly connected with family. Work with talented children consists of three stages. At the first stage, the teacher in a class will often organize work with exceptional children in initial classes. The teacher has the rights to write down gifted children with special abilities, such as painting, dance, and crafts to the centers.

At the second stage, in 5-9 classes, work with exceptional children is organized according to their cognitive, creative abilities and abilities. Here group forms of work: role trainings, scientific and practical work, purposes of projects and individual tasks from each subject. At this stage there is obvious a work of the social teacher with exceptional children as at this stage there are obvious changes in behavior of exceptional children. At the third stage, design and research products are used. Thanks to technologies of design, attention is paid to ability of pupils to acquire knowledge in the context of their own researches.

At the same time work of the social teacher grows. The social teacher - the defender of interests of the growing person. The social teacher is not the external head; he is a direct participant of joint activity of children and adults and is the leading organizer of this activity. All its efforts are directed to motivating the person to act and to social instigation to find a way out of a difficult situation, which helps to solve him problems.

The social teacher considers endowments as one of types of deviations and develops technology of work with the talented child. Psychologists, heads of classes, subject teachers, parents and the social worker carry out systematic work such. When determining talent of the child, first, marital status of the student is studied, and his creativity is defined. Then, depending on abilities of the child, he / she can develop the knowledge. The social teacher holds potential and pedagogical consultation with parents of the exceptional child for development of the unique qualities. She prepares special questionnaires and psych diagnostic preparation.

The social teacher often uses the following psychological methods for work with gifted children.

1. Test «Gifted card» (Savenkov)

2. The questionnaire for Jones's creativity

3. Diagnostics of creative abilities of students

4. Questionnaire of motivational motivation

5. Methodology of interests of a profile of the child 

poll).

6. General method of detection of teeth (parental

These methods lead to search taking into account level and the amount of self-detection of mind, emotional and social development of pupils and their features. You can carry out the following tasks to develop memory of the talented child. For example, five words in the table are read twice. Students have to distinguish quickly these words and write down them in the required sequence in one minute. (Animals, birds, trees, flowers, vessels)

Following task. When reading the teacher pupils have to write the following words. All 32 speeches: the poplar, a tree, snow, wolves, foxes, seagulls, cups, spoons, forks have to sledge, a pine, a birch, an oak, Zorman, a monkey, a duck, a goose, fir-trees, a rare tiger, a lion a scoop, a swallow, a rabbit, a swan, a Golden Eagle, a turkey, chicken, an edge, a giraffe, a bag.

Result: the list of words, which were written by pupils. If the number of words is, equal 32, then their information of good, from 31 to 29 words on average. Less than 28 words will be considered as low.

\section{Conclusion}

In conclusion, the technology of work with gifted children from the social teacher is directed to identification of their abilities and the solution of the social problems based on pedagogical process. Work of the social teacher with the gifted child includes consciousness, self-discipline, and self-improvement but also work with the talented child will help them to choose the correct profession for the future profession.

\section{References}

1 Назарбаев Н. Стратегия «Казахстан-2050»: новый политический курс состоявшегося государства. Послание Президента Казахстана народу. - Астана, 2012.

2 Закон Республики Казахстан «Об образовании». - Астана, 2007.

3 Socrates. Philosophy history in a summary. / The lane with N.N. Boguta. - M.: Thought, 1991. - 590 p.

4 Locke D. Chosen philosophical compositions. 2nd volume. T.1, M., Sots. - econ. liter. 1960-537.

5 Kant and Hegel's philosophy. World philosophical heritage. - Almaty: Writer, 2006. - T. 8. - 520 p.

6 Kunanbayev Abay. Words of edification. - Almaty: Art, 2006. - 118 p.

7 Kuznetsova S.V. Formation of intellectual actions. Under the editorship of Yu.B. Gippenreyter, V.V. Petukhova. - M, 1981. $-86 \mathrm{p}$.

8 Russian-Kazakh explanatory dictionary: Pedagogics / O.D., the head of department of the general law Aryn - Pavlodar: NPO of NPO. 2006. - Article 482

9. Leytes N.S. Age abilities of exceptional children. - M: pedagogika, 1989.

\section{References}

1 Kant and Hegel's philosophy. World philosophical heritage (2006). - Almaty: Writer, 8, 520.

2 Kunanbayev, Abay (2006). Words of edification. Almaty, Art, 118.

3 Kuznetsova S. V. (1981). Formation of intellectual actions. Under the editorship of Yu.B. Gippenreyter, V.V. Petukhova. Moscow, 86.

4 Law of the Republic of Kazakhstan on Education (2007). Astana.

5 Leytes, N.S. (1989). Age abilities of exceptional children. - M., Pedagogika.

6 Locke D. (1960). Chosen philosophical compositions, 2. T.1. Moscow, 537.

7 Nazarbayev, N. (2012). «Strategy Kazakhstan-2050»: the new political course of the established state. Address by the President of the Republic of Kazakhstan to the people of Kazakhstan. Astana.

8 Russian-Kazakh explanatory dictionary: Pedagogics (2006). Pavlodar, NPO of NPO. Article 482

9 Socrates (1991). Philosophy history in a summary. The lane with N.N. Boguta. Moscow, Thought, 590. 